\title{
Modification of the Pseudomonas syringae pv. tabaci- tobacco leaf interaction by bacterial oligosaccharides
}

\author{
E. Stefani, G. Bazzi and U. Mazzucchi* \\ Istiluto di Patologia Vegetale, University of Bologna, via F. Re 8, 40126 Bologna, Italy
}

(Accepled for publication August 1994)

\begin{abstract}
Cell-associated oligosaccharides were extracted with trichloroacetic acid treatment from Pseudomonas syringae pv. aptata, purified by column chromatography, analysed by GC-MS and fast atom bombardment-mass spectrometry, and bioassayed on tobacco leaves. The material was shown to be a mixture of neutral oligosaccharides, with a mol. wt of 800-1800, degree of polymerization 5-11, and linear glucose and mannose chains. Local infiltrations of the mixture, in concentrations of $1 \mathrm{mg}, 100,10$ and $1 \mu \mathrm{g} \mathrm{ml}^{-1}$, did not cause tobacco tissue necrosis within 1 week. When the mixture was infiltrated in the interveinal leaf panels, in concentrations of $1 \mu \mathrm{g}$, 100,10 and $1 \mathrm{ng} \mathrm{ml}^{-1}, 48 \mathrm{~h}$ before challenge inoculation, it delayed or prevented normosensitive necrosis by $P$. syringae pv. tabaci but not hypersensitive necrosis by $P$. syringae $\mathrm{pv}$. aplata. Five days after inoculation with $P$. syringae $\mathrm{pv}$. tabaci, inhibition of normosensitive necrosis, as compared with the control tissue, was $80.55,77.21,56.36$ and $45.46 \%$ for the four concentrations. In the bioassay with $P$. syringae pv, labaci the efficacy threshold was assessed at approx. $1 \mathrm{ng} \mathrm{ml}^{-1}$. Pre-treatment with oligosaccharides $\left(1 \mu \mathrm{g} \mathrm{m}^{-1}\right)$ significantly inhibited the growth of $P$. syringae pv. tabaci between 3 and 5 days after inoculation and, between day 6 and 8 , it delayed the death of bacteria when the tissue was not subject to necrosis. An interval of $6 \mathrm{~h}$ was necessary between the infiltration of oligosaccharides $\left(1 \mu \mathrm{g} \mathrm{ml}^{-1}\right)$ and inoculation of $P$. syringae pv. tabaci for a clear inhibition of normosensitive necrosis. These oligosaccharides acted as signal molecules by modifying, at nanomolar concentrations, the $P$. syringae $\mathrm{pv}$. tabaci-tobacco leaf interaction, but they were not elicitors of the hypersensitive reaction.
\end{abstract}

\section{INTRODUCTION}

Endogenous and exogenous homo- and hetero-oligosaccharides (OLSs) can act as signal molecules in plant-microbe interactions and/or as plant morphogenesis regulators [29]. They may act alone or in synergistic combination with plant.cell wall fragments evoking plant defence responses [5]. Periplasmic and other cell-associated bacterial OLSs play a role in the infection processes of Agrobacterium, Rhizobium and Bradyrhizobium in their host plants $[4,8]$. It is not known whether bacterial OLSs play a role in other plant-bacterial interactions. The active elicitor, coded by the avirulence gene D in Pseudomonas syringae pv. tomato, is a low mol. wt, thermostable compound containing a gamma-lactone ring, whose production is associated with the metabolic pathways of osmoregulating OLSs $[12,16]$.

*To whom correspondence should be addressed.

Abbreviations used in text: DP, degree of polymerization; FAB-MS, fast atom bombardment-mass spectrometry; KB, King's medium B; OLS, oligosaccharide; pr-LPS, protein-lipopolysaccharide; TCA, trichloroacetic acid; $\mathrm{YM}$, yeast mannitol broth. 
Osmoregulating, periplasmic OLSs, extracted from Gram-negative bacteria with trichloroacetic acid (TCA) treatment [25], are likely candidates for signal molecules to plant cells [20]. Periplasmic OLSs may accumulate in bacteria, suspended in the lowmolarity congestion fluid during penetration [11], and subsequently be released under inoculation stress during establishment $[6,26]$.

This paper presents evidence that OLSs, extracted with TCA treatment from $P$. syringae pv. aptata cells and purified, were able to modify in planta the homologous tobacco leaf tissue- $P$. syringae pv. tabaci interaction; but not the heterologous one with $P$. syringae pv. aptata. The OLS mixture infiltrated at least $6 \mathrm{~h}$ earlier, inhibited or prevented normosensitive necrosis and this inhibition also occurred at nanomolar concentrations.

\section{MATERIALS AND METHODS}

\section{Bacterial cultures}

The strains $P$. syringae pv. aptata NCPPB 2664 and $P$. syringae pv. tabaci NCPPB 1918 were routinely grown on YDC agar slants at $27^{\circ} \mathrm{C}$ for $24 \mathrm{~h}$. The aqueous. suspensions were calibrated at $A_{660}=0 \cdot 100$ and colony forming units (cfu) were determined from plate counts [23].

\section{OLS extraction}

The TCA method was used [25]. The bacteria were grown in yeast mannitol broth (YM) for $22 \mathrm{~h}$, up to the late log-phase, on a rotary shaker at $27^{\circ} \mathrm{C}$. The extract was concentrated with a sterile airflow at $37^{\circ} \mathrm{C}$.

\section{OLS purification}

The $1.5 \mathrm{ml}$ samples of neutralized TCA extract were chromatographed on a Sephadex G-50 column $(2.5 \times 50 \mathrm{~cm})$. The temperature of the column was thermostatically controlled at $15^{\circ} \mathrm{C}$ and eluted with $7 \%$ l-propanol; $5 \mathrm{ml}$ fractions were collected and assayed for total carbohydrates, by the phenol method [9], and for proteins according to Lowry et al. [18] and by measuring absorption at $A_{280}$. The central fractions of the peak with the highest total sugar content eluted from Sephadex G-50 were concentrated and then $1.5 \mathrm{ml}$ samples were chromatographed on a DEAE Sephacel column $(1.1 \times 25 \mathrm{~cm})$. The column was run at $15^{\circ} \mathrm{C}$ and eluted first with $10 \mathrm{~mm}$ Tris-buffer in $7 \%$ 1-propanol and then with a linear gradient of $0-100 \mathrm{~mm}$ of $\mathrm{KCl}$. Fractions $(2.0 \mathrm{ml})$ were collected and analysed for total carbohydrate content as above. The material for biochemical assays and the in planta experiments was obtained by lyophilizing the central fractions of the peak eluted in 7\% 1-propanol in the DEAE-Sephacel column without Tris-buffer and $\mathrm{KCl}$.

\section{Tobacco plants}

Tobacco plants cv. White Burley were used at the eight-ten leaf stage. The two most mature leaves with no sign of senescence were used on each plant. During the experiments the plants were kept in a climatic chamber at $25^{\circ} \mathrm{C} \pm 1 ; \mathrm{RH} 70-90 \%$, providing 12000 lux during a $14 \mathrm{~h}$ photoperiod. 


\section{Tobacco bioassays}

The lyophilized OLSs were dissolved in sterile distilled water at $1 \mathrm{mg} \mathrm{ml}^{-1}$. The distilled water (conductivity $=0.8 \mu \mathrm{S}$ ) was filtered through a $0.45 \mu \mathrm{m}$ Sartorius Filter (Cat. no. 11306, Germany) before autoclaving. This solution and three 10-fold dilutions $\left(100,10\right.$ and $1 \mu \mathrm{g} \mathrm{ml}^{-1}$ ) were locally infiltrated into interveinal panels of tobacco leaves and the plants were kept under observation for a week.

In other experiments, four 10 -fold dilutions $\left(1 \mu \mathrm{g}, 100,10\right.$ and $\left.1 \mathrm{ng} \mathrm{ml}^{-1}\right)$ were infiltrated in interveinal panels of tobacco leaves (treated tissue) with a sterile syringe. Interveinal panels of other plants were infiltrated with sterile distilled water (control tissue). Two replicates were made for each pre-treatment. After $48 \mathrm{~h}$ the treated and control tissues were locally infiltrated with suspensions of challenge bacteria, $P$. syringae pv. aptata $\left(5 \times 10^{8} \mathrm{cfu} \mathrm{m}^{-1}\right)$ and $P$. syringae pv. tabaci $\left(3 \times 10^{6} \mathrm{cfu} \mathrm{m}^{-1}\right)$. The panels were inspected each day for a week and the hypersensitive and normosensitive responses were evaluated as the percentage of collapsed and/or necrotic area as compared with the entire area infiltrated with the challenge bacteria. The experiments were repeated five times.

For other experiments, the bacterial suspension was infiltrated at different intervals (30 min, 6, 12, 24 and $36 \mathrm{~h}$ ) after infiltration of OLSs $\left(1 \mu \mathrm{g} \mathrm{m}^{-1}\right)$. Panels, preinfiltrated with water, were used as controls. Symptom development was monitored for 1 week and an assessment was made of the minimum time interval required to prevent normosensitive necrosis 4 days after each challenge inoculation.

Growth in planta

Aqueous solutions of the OLSs $\left(1 \mu \mathrm{g} \mathrm{m}^{-1}\right)$ were infiltrated in six interveinal panels per leaf with a microsyringe (treated tissue). Water-infiltrated panels were used as controls (control tissue). After $48 \mathrm{~h}$, all treated tissues were carefully infiltrated with a suspension of $P$. syringae pv. tabaci $\left(3 \times 10^{6} \mathrm{cfu} \mathrm{m}^{-1}\right)$. After bacterial infiltration, the tobacco plants were kept in the climatic chamber as for the tobacco bioassay. The first sample was taken $2 \mathrm{~h}$ after infiltration. Samples of 10 discs, $0.7 \mathrm{~cm}$ diameter, were then collected from the treated and control tissue between 3 and 8 days after infiltration. In the treated tissue, between day 5 and 8 , two sampling series were collected, the first from panels with developing necrosis and the other from non-necrotic panels. The discs were homogenized in a mortar with $1 \mathrm{ml}$ of sterile distilled water and $10 \mu \mathrm{l}$ homogenate samples were plated on King's medium B (KB) agar. Plates were incubated for $48 \mathrm{~h}$ at $27^{\circ} \mathrm{C}$ and then the number of cfu was calculated. For each assessment time a separate analysis of variance ( $F$ test) was carried out; mean numbers of bacteria in the control and treated tissues were compared according to the Dunnet test. The individual colonies counted were purified on $\mathrm{KB}$ agar plates and identified with comparative densitometric evaluation (Ultroscan 2222, Pharmacia LKB, Sweden) of the electrophoretic soluble total cell protein profiles [13].

\section{Oligosaccharide analysis}

This was performed to determine the quality and quantity of the hexose composition. Glycosyl composition was analysed with two methods: the preparation and analysis of trimethylsilyl methylglycosides and alditol acetate [33]. 
The samples were analysed by GC-MS; inositol was added as an internal standard, individual glycosyl residues were identified and quantified by comparison with authentic standards.

The OLS mol. wts were determined using fast atom bombardment-mass spectrometry (FAB-MS). FAB-MS analysis was performed on a ZAB-SE VC instrument using bioglycerol as the matrix.

\section{RESULTS}

The TCA bacterial extracts fractionated on Sephadex G-50 gave close, similar-sized carbohydrate peaks; two protein peaks were eluted after the second carbohydrate peak (Fig. 1). Fractionation of the Sephadex G-50 highest mol. wt peak separated only one

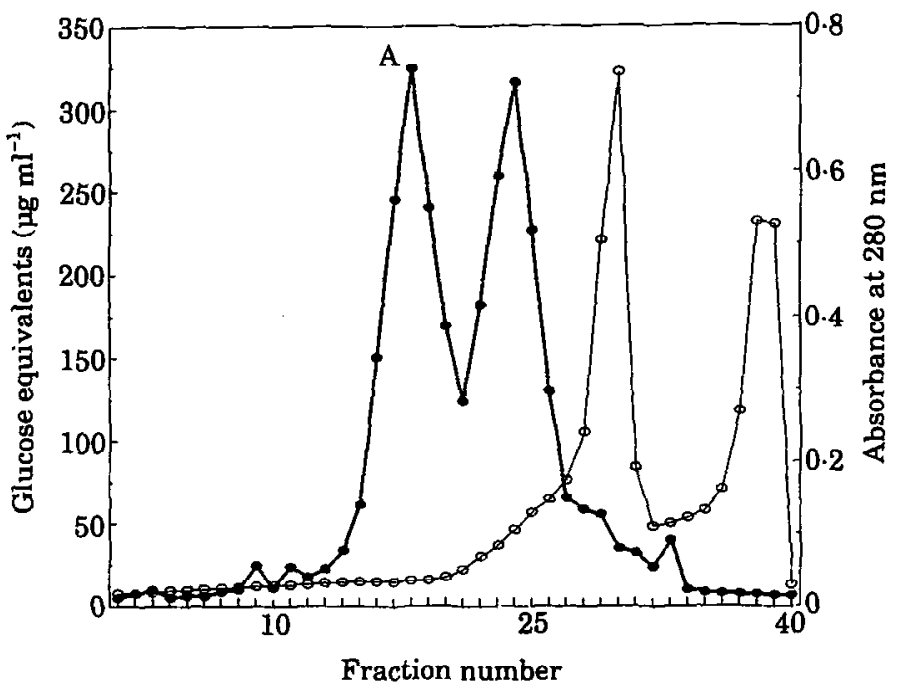

Fig. 1. Separation of oligosaccharides on Sephadex G-50. The column was eluted with $7 \% 1$. propanol and fractions $(5 \cdot 0 \mathrm{ml})$ were collected and assayed for total carbohydrates by the phenol method with glucose as standard. Results (bold line) are expressed as micrograms of equivalent glucose normalized $\mathrm{ml}^{-1}$ of eluate. Peak A was further analysed by ion exchange chromatography. Fractions were also read at $A_{280}$ : results are expressed as absorbance units.

peak not adsorbed on DEAE-Sephacel and not containing protein; no peak was detected after the formation of the $\mathrm{KGl}$ gradient (Fig. 2).

Glycosyl composition analysis showed that the material consisted of mannose and glucose (Fig. 3). No amino sugars or uronic sugars were detected. The amounts of glucose and mannose present in each sample were 106 and $652 \mu \mathrm{g} \mathrm{mg}^{-1}$, respectively. FAB-MS analysis revealed that the material consisted of some linear OLSs, all containing hexoses. Molecular weights ranged from 800-1800, corresponding to a degree of polymerization (DP) of 5-11 hexosyl residues (Fig. 4). The most intense ions were a heptamer, octamer and nonamer; $\mathrm{M}+\mathrm{NH}_{4}{ }^{+}$and in some cases $\mathrm{M}+\mathrm{Na}^{+}$were the most frequent. The fragmentation pattern suggested a sequential loss of fragment ions equivalent to 162 atomic mass units.

The $1 \mathrm{mg} \mathrm{ml}^{-1}$ concentration did not cause tobacco tissue necrosis but just a very faint chlorosis; no symptoms were induced by the 100,10 and $1 \mu \mathrm{g} \mathrm{ml}^{-1}$ concentrations. 


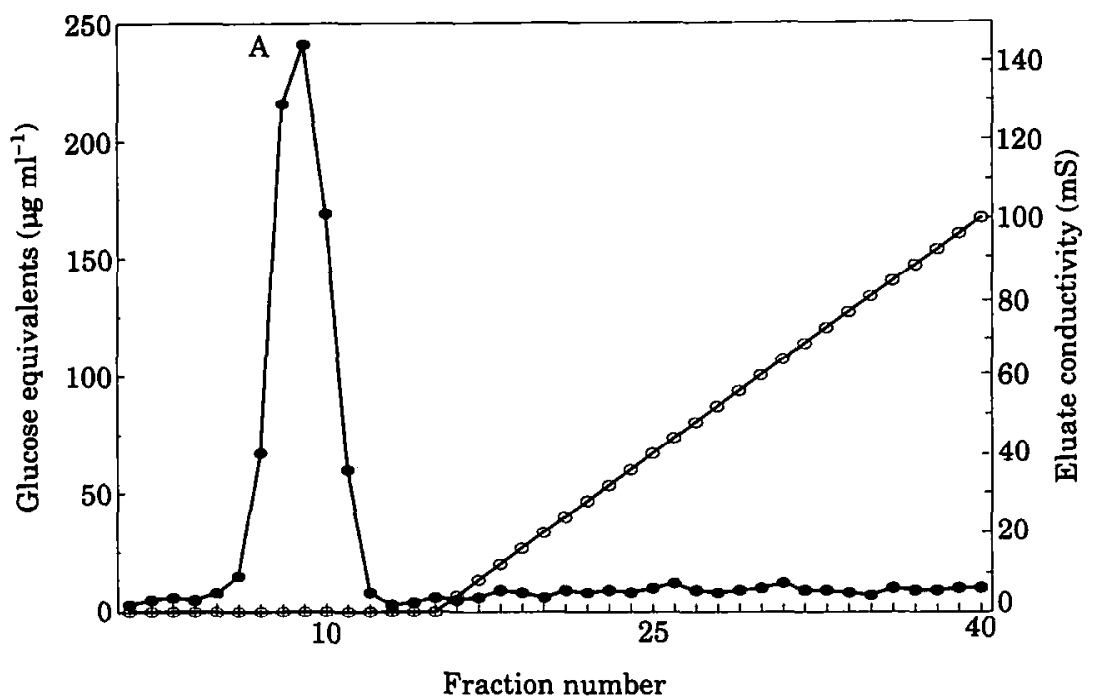

Fig. 2. Purification of oligosaccharides by DEAE-Sephacel (Pharmacia). Peak A separated on Sephadex G-50 was chromatographed. The column was eluted with $10 \mathrm{~mm}$ Tris-buffer ( $\mathrm{pH} 7 \cdot 8$ ) in $7 \% 1$-propanol and then by linear gradient of $\mathrm{KCl}(10-100 \mathrm{~mm})$. Fractions $(2.0 \mathrm{ml})$ were collected and assayed for total carbohydrates as already described for Fig. 1.

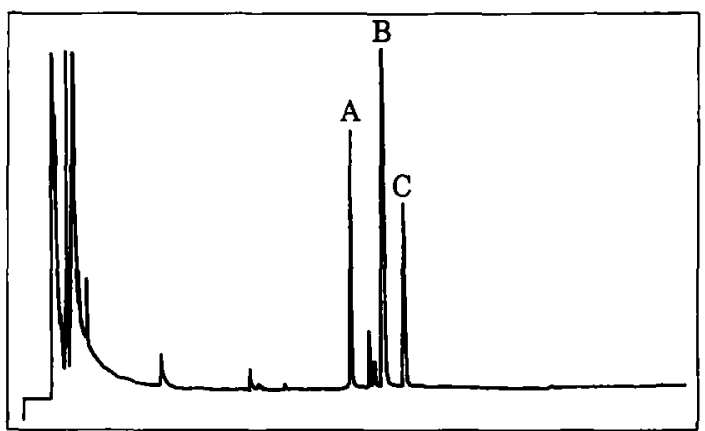

Fic. 3. Elution profile of the alditol acetate of the oligosaccharide mixture purified on DEAESephacel. An SP $233015 \mathrm{~m}$ capillary column (Supelco, U.S.A.) was used, with a temperature programme beginning at $190^{\circ} \mathrm{C}$, increasing to $240^{\circ} \mathrm{C}$ at $10^{\circ} \mathrm{C} \mathrm{min}{ }^{-1}$, with a 5 min hold at $240^{\circ} \mathrm{C}$. Inositol was used as an internal standard. A, mannose; B, glucose; C, inositol.

The challenge inoculation with $P$. syringae pv. aptata caused the collapse of treated and control tissue within $24 \mathrm{~h}$, which became necrotic in the hours that followed.

In the control tissue, inoculation with $P$. syringae pv. tabaci caused collapse and partial necrosis $(47.5 \%)$ after 3 days and almost confluent necrosis $(82.5 \%)$ after 5 days (Fig. 5). Five days after treatment with the highest OLS concentrations ( $1 \mu \mathrm{g}$ and $100 \mathrm{ng} \mathrm{m}^{-1}$ ), $P$. syringae pv. tabaci had caused marked chlorosis throughout most of the area, while necrosis only affected 15.8 and $18.8 \%$, respectively; with the same concentrations, after 6 days, there was necrosis in 53.2 and $65.8 \%$, respectively. In two experiments out of five, there was no necrosis after 7 days and the chlorosis persisted up to senescence of the leaves in plants transferred to the greenhouse. 


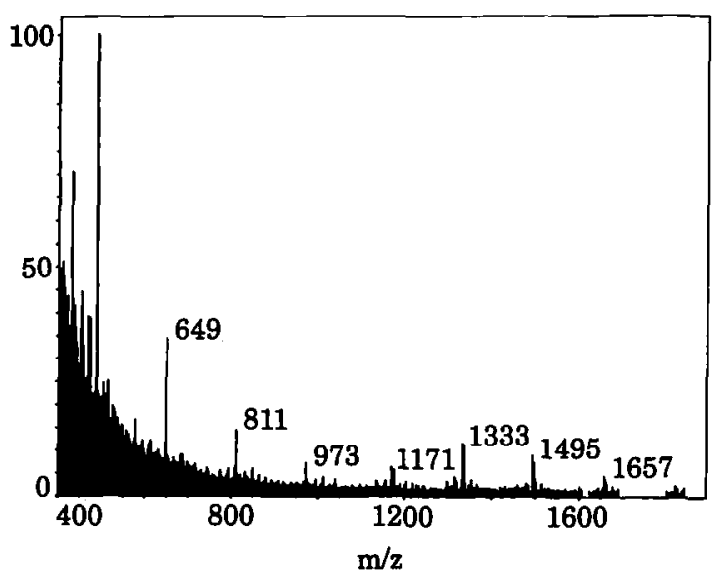

Fig. 4. Fast atom bombardment-mass spectrometry profile $(\mathrm{m} / \mathrm{z}=400-1850)$ of the mixture showing seven oligosaccharides ranging from a degree of polymerization of 5-11. Analysis was carried out using a VG ZAB-SE instrument at an accelerating voltage of $8 \mathrm{kV}$ in the positive mode. Thioglycerol was used as the matrix. The samples were dissolved in the dimethylsulphoxide and approx. $2-10 \mu \mathrm{g}$ in $1 \mu \mathrm{l}$ were applied to the probe.

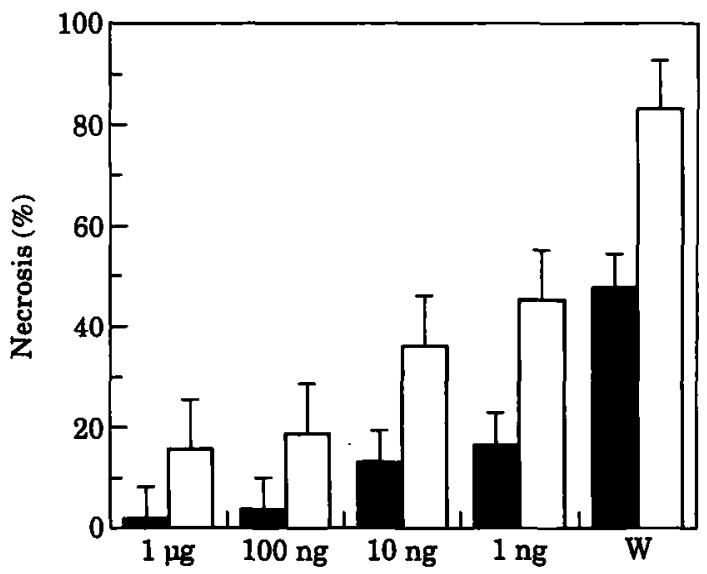

Fig. 5. Necrosis (\%) of the area inoculated with Pseudomonas syringae pv. tabaci in the interveinal panels of tobacco leaves infiltrated $48 \mathrm{~h}$ earlier with oligosaccharide concentrations of $1 \mu \mathrm{g}, 100$, 10 and $1 \mathrm{ng} \mathrm{ml}^{-1}$ (treated tissue) and with distilled water (W) (control tissue). Assessments were made 3 and 5 days after inoculation on plants kept at $25^{\circ} \mathrm{C}$ in a climatic chamber. Each pair of histograms refers to one concentration, assessed after 3 days $(\square)$ and after 5 days $(\square)$. The confidence limits are shown by the vertical bars.

In tissue treated with the lowest concentrations ( 10 and $\left.1 \mathrm{ng} \mathrm{ml}^{-1}\right)$, after 3 days $P$. syringae pv. tabaci caused collapse and partial necrosis of 12.9 and $16.4 \%$, and after 5 days of 36.0 and $45.0 \%$ (Fig. 5). In all experiments, with the same concentrations, after 6 days there was confluent necrosis indistinguishable from that $(100 \%)$ induced in the control tissue.

Preliminary experiments gave the same results, regardless of whether the 10 -fold dilutions were infiltrated into the same leaf or each one infiltrated into a separate leaf or even a separate plant. 
In the growth in planta experiments, necrosis began 3 days after challenge inoculation in the control tissue and became confluent 2 days later. Necrosis began in a series of treated tissue panels on day 5 and progressed, reaching $40 \%$ on day 8 . In the other series of panels there was no necrosis and only a slight persistent chlorosis was observed.

In the control and in the treated tissue, the $P$. syringae pv. tabaci populations increased between day 3 and 5 and then decreased (Fig. 6). Between day 3 and 5 the number

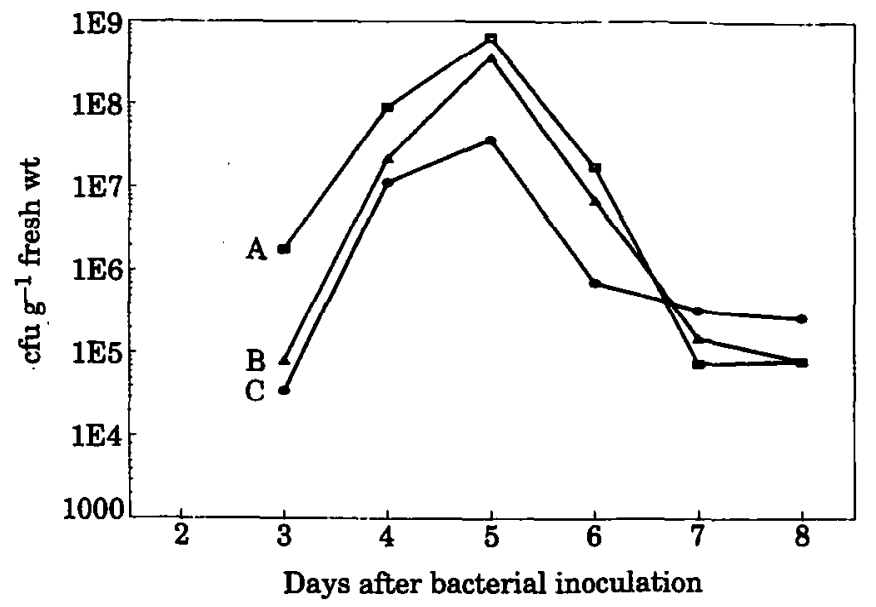

Fic. 6. Multiplication of Pseudomonas syringae pv. tabaci in tobacco mesophyll infiltrated with $1 \mu \mathrm{g} \mathrm{ml}^{-1}$ oligosaccharide solution $48 \mathrm{~h}$ before bacteria inoculation. A, control tissue; $B$, treated tissue undergoing partial necrosis; $\mathrm{C}$, treated tissue showing only slight chlorosis.

of bacteria in the control tissue was significantly higher than in the treated tissue. On days 7 and 8, while no further symptom development was observed, there was a decrease in the bacterial population in the treated tissue but not in the control. On both days, the number of bacteria in the non-necrotic treated tissue was significantly higher than in the control and the partially necrotic-treated tissue. On day 8, there was no significant difference between the number of bacteria in the necrotic control and treated tissues. Normosensitive necrosis was clearly inhibited (approx. $82 \%$ ) with a time interval of at least $6 \mathrm{~h}$.

\section{DISCUSSION}

GG-MS and FAB-MS showed that the purified TCA extract from $P$. syringae pv. aptata cells was a mixture of neutral OLSs with a mol. wt of approx. 800-1800, DP 5-11, with linear glucose and mannose chains. The $P$. syringae pv. aptata OLSs are different from the periplasmic or cell-associated cyclic $\beta-1,2$ and $\beta$-1,6 OLSs of Agrobacterium, Rhizobium and Bradyrhizobium [4].

The hypersensitive confluent necrosis caused by $P$. syringae pv. aptata occurred at the same time in all OLS-treated and control tissues. Pre-treatment of tobacco leaves with albumin [14], with heat-killed bacteria [19], with lipopolysaccharides [7], with protein-lipopolysaccharide (pr-LPS) complexes $[22,24]$ and with bacterial pectate lyase [2] prevents hypersensitive confluent necrosis and prevents or delays normo- 
sensitive necrosis. Evidently the effect of these treatments on tobacco leaf tissue is different from that induced by $P$. syringae pv. aptata OLSs. This is confirmed by the fact that the minimum time interval required to inhibit normosensitive necrosis is only about $6 \mathrm{~h}$.

After 5 days, the inhibition of normosensitive necrosis in the treated tissue, as compared with the control, was $80.85,77 \cdot 21,56.36$ and $45.46 \%$ for the four OLS concentrations ( $1 \mu \mathrm{g}$ to $1 \mathrm{ng} \mathrm{ml}^{-1}$ ); however, with the $10 \mathrm{ng}$ and $\mathrm{I} \mathrm{ng} \mathrm{ml}^{-1}$ concentrations, after 6 days, necrosis was already indistinguishable from that in the control tissue. Consequently, the minimum threshold for oligosaccharide efficacy could be evaluated at approx. $1 \mathrm{ng} \mathrm{ml}^{-1}$. Due to their regulator properties at nanomolar concentrations, the $P$. syringae pv. aptata cell-associated OLSs can be classed as oligosaccharins $[1]$.

The multiplication of $P$. syringae pv. tabaci in treated tissue was lower than in the control tissue between days 3 and 5 after inoculation. Clearly, pre-treatment with OLSs inhibited endophytic growth of $P$. syringae pv. tabaci in the first 5 days. In the control tissue, necrosis began to develop on day 3 , when the number of endophytic bacteria exceeded the critical threshold, as expected [15]. On day 4, the number of bacteria in the treated tissue was already 10 times higher than the critical threshold without causing any necrosis. Evidently the treated tissue showed tolerance towards the multiplying endophytic bacteria. This tolerance was maintained and accentuated on day 5 in the almost asymptomatic tissue, when there was a peak in the bacterial population. The $P$. syringae pv. tabaci population dynamics in the OLS pre-treated tissue differed from that of the tissue pre-treated with pr-LPS complexes, where the endophytic growth was delayed and the population peak occurred almost a day later [21].

Between day 6 and 8 , bacteria died in the pre-treated and in the control tissue; in the non-necrotic OLS-treated tissue, however, the number of bacteria on day 7 and 8 was significantly higher than in the necrotizing treated and control tissue. On the other hand, on day 8 there were the same number of bacteria in the necrotic control and treated tissues. Glearly, in the non-necrotic OLS-treated tissue bacterial death was not caused by mere confluent necrosis as occurs in the terminal stage of natural leaf spot development [17]. This indicates that pre-treatment with OLS caused a significant change in the $P$. syringae pv. tabaci-tobacco cell interaction.

Our OLS mixture, infiltrated in tobacco leaves, prevented or delayed normosensitive necrosis caused by a virulent $P$. syringae pv. tabaci strain. These OLSs, modifying the tobacco leaf tissue response to the homologous challenge bacterium, acted as signal molecules, but our data are not sufficient to establish the molecular basis of their interference. To act as a mobile signal for plant cells, an OLS must have a diameter of less than 3-5 nm [20] and a DP of less than approx. 20 [27]. In fact, most homoand hetero-OLSs evoking plant responses have a DP of 3-13 $[2,3,10,28,29,31]$. $P$. syringae pv. aptata cell-associated OLSs, like those of Bradyrhizobium (DP $=10-13$ ), but unlike most of Agrobacterium or Rhizobium (DP =17-24), meet the requirements for mobile signal molecules. They may have directly modulated the expression of the $h r p$ genes of the challenge bacterium in the first stages of the interaction [30,32]. More likely, OLS pre-treatment could have evoked a plant cell response conditioning the subsequent challenge inoculation. 
Although the TCA extraction method used here extracts the osmoregulator periplasmic OLSs from Gram-negative bacteria [25], the cell localization of $P$. syringae pv. aptata OLSs is unknown. Further studies are necessary to determine the role of these types of OLSs in pathogenesis and highlight the most active components. Apparently, none of these was an hypersensitive response elicitor, since the $1 \mathrm{mg} \mathrm{ml} \mathbf{m}^{-1}$ concentration did not cause necrosis in tobacco leaves. Other pseudomonads belonging to the $P$. syringae species appear to produce similar OLS mixtures (Stefani, unpublished).

This research was supported by the Italian National Research Council, Special RAISA Project, Sub-project no. 2, Paper No. 1933, and in part by funds from the Department of Energy-funded (DE-FG05-93ER20097) Center for Plant and Microbial Complex Carbohydrates. We would like to thank $\mathrm{Dr} \mathrm{R}$. W. Carlson at the Complex Carbohydrate Research Centre (Georgia, U.S.A.) for his work with mass spectrometry techniques.

\section{REFERENCES}

1. Albersheim P, Darvill AG, McNeil M, Valent BS, Sharp JK, Nothnagel EA, Davis KR, Yamazaki N, Gollin DJ, York DJ, York WS, Dudman WF, Darvill ED, Dell A. 1983. Oligosaccharins, naturally occurring carbohydrates with biological regulatory functions. In: Ciferri O, Dure L III, ed. Structure and Function of Plant Genomes, New York: Plenum Press, 293-312.

2. Baker GJ, Atkinson MM, Roy MA, Collmer AS. 1986. Inhibition of the hypersensitive response in tobacco by pectate lyase. Physiological and Molecular Plant Pathology 29: 217-225.

3. Barber MS, Bertram RF, Ride JP. 1989. Chitin oligosaccharides elicit lignification in wounded wheat leaves. Physiological and Molecular Plant Pathology 34: 3-12.

4. Breedveld MW, Miller KJ. 1994. Cyclic $\beta$-glucans of members of the family Rhizobiaceae. Microbiological Review 58: 145-161.

5. Darvill AG, Albersheim P. 1984. Phytoalexins and their elicitors-a defense against microbial infection in plants. Annual Review of Plant Physiology 35: 234-275.

6. Decad JM, Nikaido H. 1976. Outer membrane of gram-negative bacteria XII. Molecular-sieving function of cell wall. Journal of Bacteriology 128: 325-336.

7. Graham TL, Sequeira L, Huang TR. 1977. Bacterial lipopolysaccharides as inducers of disease resistance in tobacco. Applied and Environmental Microbiology 34: 424-432.

8. Gray JX, de Mangd RA, Rolfe BA, Johnston AWB, Lugtenberg BJJ. 1992. The role of the Rhizobium cell surface during symbiosis. In: Verma DPS, ed. Molecular Signals in Plant-Microbe Communications. Boca Raton: C.R.C. Press, 359-376.

9. Hanson RS, Phillips JA. 1981. Chemical composition. in: Gerhardt P, Murray RGE, Costilow RN, Nester EW, Wood WA, Krieg NR, Phillips GB, ed. Manual of Methods for General Microbiology. Washington D.C.: American Society for Microbiology, 328-364.

10. Jin DF, West CA. 1984. Characteristics of galacturonic acid oligomers as elicitors of casbene synthetase activity in Castor bean seedlings. Plant Physiology 74: 989-992.

11. Johnsion J. 1945. Infection experiments with detached water-congested leaves. Phytopathology 35 : $1017-1028$.

12. Keen N, Kobayashi D, Tamaki S, Shen H, Stayon M, Lawrence D, Sharma A, Midland S, Smith M, Sims J. 1991. Avirulence gene D from Pseudomonas syringae pv. tomato and its interaction with resistance gene Rpg4 in soybean. In: Herrnecke H, Verma DPS, ed. Advances in Molecular Genetics of Plant-Microbe Interactions, I. Dordrecht: Kluwer Academic Publishers, 37-44.

13. Kersters K. 1990. Polyacrilamide gel electrophoresis of bacterial proteins. In: Klement Z, Rudolph K, Sands DC, ed. Methods in Phytobacteriology. Budapest: Akadémiai Kiadó, 191-198.

14. Kiraly Z, Hevesi M, Klement Z. 1977. Inhibition of bacterial multiplication in incompatible host-parasite relationship in the absence of the hypersensitive necrosis. Acta Phylopathologica Academiae Scientiarum Hungaricae 12: 247-256.

15. Klement Z, Hevesi M, Sasser M. 1978. Mechanism of the development of wildfire disease in susceptible plant. Proceedings of the 4th International Conference on Plant Pathogenic Bacteria. Angers: Station de Pathologie Végétale et Phytobactériologie, 679-685. 
16. Kobayashi D, Stayon M, Keen N. 1991. E. coli galU mutant blocks avirulence gene D elicitor production in culture. Phytopathology 81 : 1.187 (Abstr.).

17. Lovrekovich L, Farkas GL. 1965. Induced protection against wildfire disease in tobacco leaves treated with heat-killed bacteria. Nature 205: 823-824.

18. Lowry OH, Rosenbrough NJ, Farr AL, Randall RJ. 1951. Protein measurement with the Folin phenol reagent. Journal of Biological Chemistry 193: 165-275.

19. Lozano JG, Sequeira L. 1970. Prevention of the hypersensitive reaction in tobacco leaves by heat-killed bacterial cells. Phytopathology 60: 875-879.

20. Mazzucchi U. 1983. Recognition of bacteria by plants. In: Callow JA, ed. Biochemical Plant Pathology. Chichester: John Wiley, 299-324.

21. Mazzucchi U, Bazzi C, Medeghini Bonatti P. 1982. Encápsulation of Pseudomonas syringae pv. labaci in relation to its growth in tobacco leaves both pretreated and not pretreated with proteinlipopolysaccharide complexes. Physiological Plant Pathology 21: 105-112.

22. Mazzucchi U, Bazzi G, Pupillo P. 1979. The inhibition of susceptible and hypersensitive reactions by protein-lipopolysaccharide complexes from phytopathogenic pseudomonads: relationship to polysaccharide antigenic determinants. Physiological Plant Pathology 14: 19-30.

23. Mazzucchi U, Comelli R. 1977. Evidence against penetration of Pseudomonas syringae into sugar beet seeds. Phytopathologische Zeitschrift 88: 355-361.

24. Mazzucchi U, Pupillo P. 1976. Prevention of confluent hypersensitive necrosis in tobacco leaves by a bacterial protein-lipopolysaccharide complex. Physiological Plant Pathology 9: 101-112.

25. Miller KJ, Kennedy EP, Reinhold VN. 1986. Osmotic adaptation by gram-negative bacteria: possible role for periplasmic oligosaccharides. Science 231 ; 48-51.

26. Minardi P, Fede A, Mazzucchi U. 1989. Protection induced by protein-lipopolysaccharide complexes in tobacco leaves: role of protected tissue free-space solutes. Journal of Phytopathology 127: 211-220.

27. Rees DA. 1977. Polysaccharide Shapes. London: Chapman \& Hall.

28. Robertson B. 1986. Elicitors of the production of lignin-like compounds in cucumber hypocotyls. Physiological and Molecular Plant Pathology 28: 137-148.

29. Ryan CA. 1987. Oligosaccharide signalling in plants. Annual Review of Cell Biology 3: 295-317.

30. Wei Z, Sneath BJ, Beer SV. 1992. Expression of Erwinia amylovora hrp genes in response to environmental stimuli. Journal of Bacteriology 174: 1875-1882.

31. West CA, Moesta AP, Jin DF, Lois AF, Wickham KA. 1985. The role of pectic fragments of the plant cell wall in the response to biological stresses. Key JL, Kosuge T, ed. New York: Alan R. Liss Inc., 335-349.

32. Winans SC. 1992. Two-way chemical signalling in Agrobacterium-plant interactions. Microbiological Review 56: 12-31.

33. York WS, Darvill AG, McNeil M, Stevenson TT, Albersheim P. 1985. Isolation and characterization of plant cell walls and cell wall components. In: Weissbach $A$, Weissbach $\mathrm{H}$, ed. Methods in Enzymology. London: Academic Press Inc. 118: 3-40. 